\title{
Study on Influence of FYM Doses and NPK on Growth Yield and Quality of Hybrid Cucumber (Cucumis sativus L.) under Shade Net
}

\author{
Patil Sruthi* and V. M. Prasad \\ Department of Horticulture, Naini Agricultural Institute, SHUATS, \\ Prayagraj, Uttar Pradesh, India \\ *Corresponding author
}

\begin{tabular}{l} 
Ke y w o r d s \\
$\begin{array}{l}\text { Cucumis sativus, } \\
\text { Growth and } \\
\text { Quality, FYM, NPK } \\
\text { and Yield }\end{array}$ \\
Article Info \\
$\begin{array}{l}\text { Accepted: } \\
\text { 26 September } 2020 \\
\text { Available Online: } \\
\text { 10 October } 2020\end{array}$ \\
\hline
\end{tabular}

\section{A B S T R A C T}

Cucumber is thought to be one of the oldest vegetable crops. A field experiment was conducted at a Department of Horticulture, Sam Higginbottom University of Agriculture, technology and sciences, Allahabad (up) India, during the Zaid (March -June) 2019-2020, to study the "Effect of FYM doses and NPK on Growth Yield and Quality of Hybrid Cucumber under shade net (Cucumis saivus L.) experiment was laid out in Randomized block design with three replications consisted six treatments combinations T0 (Control), T1 (FYM 20\% + NPK 150:120:120) T2 (FYM 40\% + NPK 150:120:120), T3 (FYM 60\% + NPK 150:120:120), T4 (FYM 80\% + NPK 150:120:120), T5 (FYM 100\% + NPK150:120:120). We are allotted randomly in each plot. The results showed that the treatment T5 (FYM 100\% + NPK 150:120:120) significantly found best among all treatments at all successive growth stages in terms of growth parameters. Whereas Maximum plant height $(326.79 \mathrm{~cm})$, Number of Leaves (122.27) and Number of Branches per plant (4.30) as growth parameters. Whereas Maximum fruit length $(16.33 \mathrm{~cm})$ fruit diameter $(15.69 \mathrm{~cm})$, Average fruit Weight $(145.61 \mathrm{~g})$ fruit Yield per plot $(17.69 \mathrm{Kg})$, and Yield per/ha (81.90t /ha) as yield related traits also recorded Maximum with TSS (4.90 brix) and Vitamin C (8.54)/100g of fruit pulp, as quality parameters. While lowest response in terms of growth, Yield, quality of Cucumber recorded with T0 (Control) which received no treatments.

\section{Introduction}

The cucumber (Cucumis sativus L.) belongs to the cucurbitaceae family, normally, cucumber plants are monoecious - they produce both male and female flowers on the same plant. India is the second largest producer of vegetables in the world after China. Cucurbits are largest group of summer season vegetables and extensively grown in tropical, subtropical and milder zones of India. Among the vegetable crop, cucumber (Cucumis sativus $\mathrm{L} ; 2 \mathrm{n}=14$ ) is considered as one of the major vegetables crops in India and in the world. Cucumber is considered as fourth most important crop after tomato, cabbage and onion. It is warm season vegetable crops primarily grow for processing (pickling) or for fresh market (slicing). It contains $96.3 \mathrm{~g}$ water, $0.4 \mathrm{~g}$ protein, $0.1 \mathrm{~g}$ fat, 
$0.3 \mathrm{~g}$ minerals, $0.4 \mathrm{~g}$ fiber, $2.5 \mathrm{~g}$ carbohydrate, 13 kcal energy, $10 \mathrm{mg}$ calcium $25 \mathrm{mg}$ Phosphorus mg iron $0.3 \mathrm{mg}$ Thiamine $0.2 \mathrm{mg}$ Niacin $7 \mathrm{mg}$ Vitamin C per $100 \mathrm{~g}$ edible portion (Goplan et al., 1982).

Cucumis comprises a genus nearly 40 species Whitaker and Davis (1967) including several of considerable importance such as Cucumber (Cucumis sativus), Muskmelon (Cucumis melo) and west Indian Gherkin (Cucumis anguria). all species are indigenous belong to Africa which apparently were introduced to West Indies from Africa and Cucumis sativus and Cucumis hardwickii are native of Asia Robinson and Whitaker (1974).

The global production of cucumber is 71.36 million tonnes (FAOSTAT 2014) and commercially cultivated in countries like China, India, Turkey, Iran, Japan, Europe and United States. In the world more than 55 countries adopted protected cultivation technology; China has the largest area of $2.7 \mathrm{mha}$ under protected. The first exposure of India to hi-tech protected cultivation of vegetables and other high-value horticultural crops realized through the Indo-Israel Project on greenhouse cultivation, initiated at the New Delhi-based Indian Agricultural Research Institute (IARI) in 1998, presently it is known as the Centre for Protected Cultivation Technology (CPCT).The total area covered under protected cultivation in India country is approximately 30,000 hectares contributes $0.23 \%$ of the total area under the horticulture cultivation in India at end of $11^{\text {th }}$ five year plan

Polyhouse protect the crops from adverse conditions like excess solar radiation, extreme temperature, rain, pest and disease. It also increased the productivity and improved quality of produce due to increase in photosynthetic rate and better management. One of the main factors affecting crop productivity under polyhouse is plant population, improper nutrients leading to deshaped fruits also and growing methods which is mainly governed by plant architecture.

Cucumber requires large quantities of both macro and micro nutrients for required of economic yields of cucumber. Nitrogen, phosphate and potash are important and play a key role in the production of both quantity and quality level in cucumber.

Cucumber plants should be fertilized with adequate dose of nitrogen, phosphorus and potassium which are the main elements and affect the growth of plants. Effect of nitrogen on vegetative and fruit yield is more obvious than other nutrients, as it promotes the setting of flower and fruits. Phosphorus (P) is an essential part of the process of photosynthesis involved in the formation of all oils, sugars and starches and effects rapid growth, encourages blooming and root growth.

The indiscriminate uses of chemical fertilizers alter the soil fertility and increase the cost of production as well. However, considering the recent concept of eco-friendly and increase in cost of inorganic and organic fertilizers, the use of cost effective and eco- friendly organic manures with suitable integration of inorganic fertilizers restores the soil health while keeping the soil productive and sustainable. Among the organic sources, the old age concept of nutrient application is the utilization of farm yard manure is easily prepared and much effective manure and Fresh poultry manure represents about $5 \%$ of live bird weight. These manures being good source of essential plant nutrients especially NPK and give good crop stand by virtue of improvement in physical, chemical and biological characteristics of the soil Singh et al., (2017). 
Farmyard manure release nutrients slowly and steadily and activates soil microbial biomass. Organic manures can sustain cropping systems through better nutrient recycling and improvement of soil physical attributes (ElShakweer et al., 1998). The use of inorganic fertilizer has not been helpful under intensiveagriculturebecauseofitshighcostanditi softenassociatedwithreducedcrop yields, soil degradation, nutrient imbalance and acidity.

The complementary use of organic and inorganic fertilizers has been recommended for sustenance of long term cropping in the tropic). Fuchs et al., (1970) reported that nutrients from mineral fertilizers enhance the establishment of crops while those from mineralization of organic manures promoted yield when both fertilizers were combined. Titiloye (1982) reported that the most satisfactory method of increasing maize yield was by judicious combination of organic wastes and inorganic fertilizers. It has been observed that addition of manure increases the soil water holding capacity and this means that nutrients would be made more available to crops where manures have been added to the soil (Costa et al., 1991).

Murwira and Kirchman (1993) observed that nutrient use efficiency might be increased through the combination of manure and inorganic fertilizer. This study was therefore conducted to investigate the effects of varying rates of Farmyard manure and inorganic fertilizers on growth of cucumber.

\section{Materials and Methods}

The present investigation was carried out during winter season during 2019-2020 at Vegetable Research Farm. Department of Horticulture, Naini Agriculture Institute, Sam Higginbottom University of Agriculture, Technology and Sciences, Prayagraj (U.P.), India. Prayagraj has a subtropical and semiarid climatic condition, south-eastern part of
Uttar Pradesh prevails with both extremes of temperature during the crop season, i.e. $13^{0} \mathrm{C}$ to $45^{\circ} \mathrm{C}$. The average rainfall in this area is about $1100 \mathrm{~mm}$ per annum.

The soils were characterized as sandy loam in texture with $\mathrm{pH} 6.8$ analyzed using glass electrode pH (Richards, 1954), available N $0.092 \%$ Modified Kjeldal's method (Jackson, 1967), available $\mathrm{P} \quad 0.80 \%$, analyzed Bicarbonate extractable ' $\mathrm{P}$ ' and development of blue colour (Jackson, 1967), available K $0.54 \%$ analyzed by Neutral normal ammonium acetate method (Jackson, 1967)

The experiment was laid out in Randomized Block Design. There were 6treatments and each replicated thrice. Treatments were allocated randomly to each replication. $\mathrm{T}_{0^{-}}$ Control, $\mathrm{T}_{1}$. FYM 20\%+NPK (150:120:120) $\mathrm{T}_{2}$-FYM40\%+ NPK (150:120:120), $\mathrm{T}_{3}-\mathrm{FYM}$ $60 \%+$ NPK (150:120:120), T 4 -FYM 80\%+ NPK (150:120:120), T - FYM 100\%+NPK (150:120:120). For growth attributes, the plant height of the four vines were measured with the help of meter tape after 90 days of sowing in centimeter and average was calculated, The open leaves of all the four plant from each plot were counted, average and analyzed 90 DAT, The open number of branches per plant of all the four plant from each plot were counted, average and analyzed 90 DAT.

For quantitative attributes, Days to first appearance of male flower of four observational vines were counted from sowing date to first appearance of male flower. The total value was average out in days, Days to first appearance of female flower of four observational vines were counted from sowing date to first appearance of female flower. The total value was average out in days, Number of male flowers of all the four vines from each plot was counted and average number of male flowers per vine was calculated, Number of fruits harvested from 
each observational vine at each harvesting was counted. Number of fruits harvested from the observational vines at different pickings were added and mean number of per vine harvested during the seasons was worked out, Fruit diameter of four randomly selected fruits was measured in $\mathrm{cm}$ and average diameter was calculated. A random sample of four full grown fruits was taken from each plant to record fruit length. Length was measured from peduncle end of fruit to blossom scar point with help of measuring tape. Total length of four fruits were divided by four to obtain average length of full grown fruit of the hybrid in particular replication, The four edible green fruits was harvested. The weight of harvested fruits measured with the help of weighing balance in gram. After measuring average was calculated. The total edible green fruit yield overall the picking was recorded for each plot and yield expressed as per vine by dividing number of vines, at first total fruit yield was counted per plot then it was converted into tonnes per hectare.

For qualitative attributes Total soluble solid was determined with the help of Erma hand refract meter (0.32 range), averaged and analyzed. To acquire ascorbic acid, the juice was filtered through muslin cloth $10 \mathrm{ml}$ (W) of the juice was taken with the help of a pipette in $100 \mathrm{ml}$ volumetric flask and the volume $\left(\mathrm{V}_{1}\right)$ was made up with $1.0 \%$ oxalic acid solution. The flask was then shaken well. The juice was then filtered known quality $\left(\mathrm{V}_{2}\right)$ of the solution was titrate against standard dye (V) solution till a faint pink colour appeared and persisted for 15 seconds.

The data from the experiments were analyzed statistically, wherever treatment differences were found significant, the critical differences were worked out at $5 \%$ level of probability $(P=0.05)$.

\section{Results and Discussion}

The maximum number of leaves per plant (122.27) was recorded with $\mathrm{T}_{5}$ (FYM $100 \%+$ NPK (150:120:120) followed by $\mathrm{T}_{4}$ (FYM $80 \%$ + NPK (150:120:120) i.e. (111.27), $\mathrm{T}_{3}$ (FYM 60\% + NPK (150:120:120) i.e. (95.75) and $\mathrm{T}_{2}$ (FYM40\% + NPK (150:120:120) i.e.(95.01). Better availability of nitrogen and potassium of higher rates seems to have augmented the number of leaves per plant.

The maximum number of branches plant ${ }^{-1}$ (4.30) was recorded with $\mathrm{T}_{5}$ (FYM $100 \%+N P K \quad(150: 120: 120)$ followed by $\mathrm{T}_{4}$ (FYM 80\% + NPK (150:120:120) i.e. (3.79), $\mathrm{T}_{3}$ (FYM 60\% + NPK (150:120:120) i.e. (3.52) and $\mathrm{T}_{2} \quad$ (FYM40\% + NPK (150:120:120) i.e. (3.39). The same result of number of leaves and maximum number of branches per plant was reported by Umamaheswarappa et al., (2005).

The minimum days to first flowering (32.09) was recorded with $\mathrm{T}_{5}$ (FYM 100\% + NPK (150:120:120) followed by $\mathrm{T}_{4}$ (FYM $80 \%+$ NPK (150:120:120) i.e. (32.98), T 3 (FYM 60 $\%+$ NPK (150:120:120) i.e. (33.08) and $\mathrm{T}_{2}$ (FYM40\% + NPK (150:120:120) i.e. (34.33).

The minimum days to $50 \%$ flowering (44.75) was recorded with $\mathrm{T}_{5}$ (FYM 100\% + NPK (150:120:120) followed by $\mathrm{T}_{4}$ (FYM $80 \%+$ NPK (150:120:120) i.e. (45.77), $\mathrm{T}_{3}$ (FYM $60 \%+$ NPK (150:120:120) i.e. (46.43) and $\mathrm{T}_{2}$ (FYM40\% + NPK (150:120:120) i.e. (47.58). Similar findings were reported by Bindiya et al., (2006) in cucumber.

The minimum days to male flowering (28.08) was recorded with $\mathrm{T}_{5}$ (FYM 100\% + NPK (150:120:120) followed by $\mathrm{T}_{4}$ (FYM 80\% + NPK (150:120:120) i.e. (29.46), T3 (FYM60 $\%+$ NPK (150:120:120) i.e. (30.13) and $\mathrm{T}_{2}$ (FYM40\% + NPK (150:120:120) i.e. (30.41). Better availability of nitrogen and potassium 
of higher rates seems to have augmented the appearance of first male flower. The best result was reported by Sinikov et al., (1992) and Haffman (1959).

Tables.1, 2 \& 3 Study on Influence of FYM Doses and NPK on Growth Yield and Quality of Hybrid Cucumber (Cucumis sativus L.) under Shade Net

\begin{tabular}{|c|c|c|c|c|}
\hline & Treatment combinations & $\begin{array}{c}\text { Plant height } \\
(\mathbf{c m})\end{array}$ & $\begin{array}{c}\text { Number of } \\
\text { leaves per } \\
\text { plant }\end{array}$ & $\begin{array}{c}\text { Number of } \\
\text { Branches per } \\
\text { plant }\end{array}$ \\
\hline $\mathbf{T}_{\mathbf{0}}$ & Control & 218.11 & 81.49 & 2.4 \\
\hline $\mathbf{T}_{\mathbf{1}}$ & FYM 20\%+NPK (150:120:120) & 282.65 & 87.93 & 3.18 \\
\hline $\mathbf{T}_{\mathbf{2}}$ & FYM40\%+ NPK(150:120:120) & 292.89 & 95.01 & 3.39 \\
\hline $\mathbf{T}_{\mathbf{3}}$ & FYM 60\%+ NPK(150:120:120) & 298.48 & 95.75 & 3.52 \\
\hline $\mathbf{T}_{\mathbf{4}}$ & FYM 80\%+ NPK(150:120:120) & 318.56 & 111.27 & 3.79 \\
\hline $\mathbf{T}_{\mathbf{5}}$ & FYM 100\%+NPK(150:120:120) & 326.79 & 122.27 & 4.3 \\
\hline & F-test & $\mathbf{S}$ & $\mathbf{S}$ & $\mathbf{S}$ \\
\hline & C.D. at 0.5\% & $\mathbf{2 . 5 3 4}$ & $\mathbf{4 . 3 1 8}$ & $\mathbf{0 . 1 1 4}$ \\
\hline & S.Ed. $(\mathbf{+}$ & $\mathbf{1 . 1 3 7}$ & $\mathbf{1 . 9 3 8}$ & $\mathbf{0 . 0 5 1}$ \\
\hline
\end{tabular}

\begin{tabular}{|c|c|c|c|c|c|c|c|c|c|}
\hline Treatment & $\begin{array}{c}\text { Days to } \\
\text { first } \\
\text { flowering }\end{array}$ & $\begin{array}{c}\text { Days to } \\
\mathbf{5 0 \%} \\
\text { flowering }\end{array}$ & $\begin{array}{c}\text { Days to } \\
\text { male } \\
\text { flowering }\end{array}$ & $\begin{array}{c}\text { Days to } \\
\text { female } \\
\text { flowering }\end{array}$ & $\begin{array}{c}\text { Number of } \\
\text { fruit per } \\
\text { plant }\end{array}$ & $\begin{array}{c}\text { Number } \\
\text { of fruit } \\
\text { per plot }\end{array}$ & $\begin{array}{c}\text { Fruit } \\
\text { length } \\
\text { (cm) }\end{array}$ & $\begin{array}{c}\text { Fruit } \\
\text { diameter } \\
\text { (cm) }\end{array}$ & $\begin{array}{c}\text { Fruit } \\
\text { weight } \\
\text { (g) }\end{array}$ \\
\hline $\mathbf{T}_{\mathbf{0}}$ & 36.54 & 52.72 & 32.42 & 36.85 & 5 & 40 & 13.29 & 11.37 & 118.52 \\
\hline $\mathbf{T}_{\mathbf{1}}$ & 35.27 & 48.49 & 31.49 & 33.8 & 12.02 & 96.13 & 14.56 & 12.76 & 127.59 \\
\hline $\mathbf{T}_{\mathbf{2}}$ & 34.33 & 47.58 & 30.41 & 32.73 & 12.12 & 96.96 & 14.83 & 13.53 & 130.47 \\
\hline $\mathbf{T}_{\mathbf{3}}$ & 33.08 & 46.43 & 30.13 & 32 & 13.53 & 108.24 & 15.48 & 13.59 & 136.69 \\
\hline $\mathbf{T}_{\mathbf{4}}$ & 32.98 & 45.77 & 29.46 & 31.01 & 14.34 & 114.75 & 15.49 & 14.24 & 138.62 \\
\hline $\mathbf{T}_{\mathbf{5}}$ & 32.09 & 44.75 & 28.08 & 30.45 & 15.19 & 121.49 & 16.33 & 15.69 & 145.61 \\
\hline F-test & $\mathbf{S}$ & $\mathbf{S}$ & $\mathbf{S}$ & $\mathbf{S}$ & $\mathbf{S}$ & $\mathbf{S}$ & $\mathbf{S}$ & $\mathbf{S}$ & $\mathbf{S}$ \\
\hline C.D@ 0.5\% & $\mathbf{0 . 9 3 7}$ & $\mathbf{0 . 8 4 8}$ & $\mathbf{0 . 5 4 4}$ & $\mathbf{1 . 0 8 9}$ & $\mathbf{1 . 3 1 7}$ & $\mathbf{1 0 . 5 4}$ & $\mathbf{0 . 2 2 8}$ & $\mathbf{0 . 4}$ & $\mathbf{0 . 3 0 8}$ \\
\hline S.Ed. $\mathbf{(} \mathbf{m}$ & $\mathbf{0 . 4 2 1}$ & $\mathbf{0 . 3 8 1}$ & $\mathbf{0 . 2 4 4}$ & $\mathbf{0 . 4 8 9}$ & $\mathbf{0 . 5 9 1}$ & $\mathbf{4 . 7 3}$ & $\mathbf{0 . 1 0 2}$ & $\mathbf{0 . 1 8}$ & $\mathbf{0 . 1 3 8}$ \\
\hline
\end{tabular}

\begin{tabular}{|c|c|c|c|c|c|c|c|}
\hline & Treatment combinations & $\begin{array}{c}\text { Days to } \\
\text { first } \\
\text { harvest of } \\
\text { cucumber }\end{array}$ & $\begin{array}{c}\text { Fruit yield } \\
\text { per plant } \\
(\mathbf{k g})\end{array}$ & $\begin{array}{c}\text { Fruit } \\
\text { yield } \\
\text { per plot } \\
\text { (kg) }\end{array}$ & $\begin{array}{c}\text { Fruit } \\
\text { yield }(\mathbf{t} \\
\left.\text { ha }^{-1}\right)\end{array}$ & $\begin{array}{c}\text { TSS } \\
\text { (Brix) }\end{array}$ & $\begin{array}{c}\text { Vitamin } \\
\text { C }\end{array}$ \\
\hline $\mathbf{T}_{\mathbf{0}}$ & Control & 64.53 & 0.59 & 4.74 & 21.95 & 3.16 & 5.16 \\
\hline $\mathbf{T}_{\mathbf{1}}$ & FYM 20\%+NPK(150:120:120) & 62.4 & 1.53 & 12.27 & 56.78 & 3.46 & 6.83 \\
\hline $\mathbf{T}_{\mathbf{2}}$ & FYM40\%+ NPK (150:120:120) & 60.55 & 1.58 & 12.65 & 58.56 & 3.79 & 7.31 \\
\hline $\mathbf{T}_{\mathbf{3}}$ & FYM 60\%+ NPK(150:120:120) & 59.15 & 1.85 & 14.8 & 68.5 & 4.25 & 7.53 \\
\hline $\mathbf{T}_{\mathbf{4}}$ & FYM 80\%+ NPK (150:120:120) & 56.73 & 1.99 & 15.91 & 73.64 & 4.41 & 7.91 \\
\hline $\mathbf{T}_{\mathbf{5}}$ & FYM 100\%+NPK(150:120:120) & 55.48 & 2.21 & 17.69 & 81.9 & 4.9 & 8.54 \\
\hline & F-test & $\mathbf{S}$ & $\mathbf{S}$ & $\mathbf{S}$ & $\mathbf{S}$ & $\mathbf{S}$ & $\mathbf{S}$ \\
\hline & C.D. at $\mathbf{0 . 5 \%}$ & $\mathbf{0 . 8 6}$ & $\mathbf{0 . 1 7 9}$ & $\mathbf{1 . 4 2 8}$ & $\mathbf{6 . 6 1}$ & $\mathbf{0 . 1 1 6}$ & $\mathbf{0 . 1 0 9}$ \\
\hline & S.Ed. $( \pm)$ & $\mathbf{0 . 3 8 6}$ & $\mathbf{0 . 0 8}$ & $\mathbf{0 . 6 4 1}$ & $\mathbf{2 . 9 6}$ & $\mathbf{0 . 0 5 2}$ & $\mathbf{0 . 0 4 9}$ \\
\hline
\end{tabular}


The minimum days to female flowering (30.45) was recorded with $\mathrm{T}_{5}$ (FYM $100 \%+$ NPK (150:120:120) followed by $\mathrm{T}_{4}$ (FYM $80 \%+$ NPK (150:120:120) i.e. (31.01), $\mathrm{T}_{3}$ (FYM60\% + NPK (150:120:120) i.e. (32.00) and $\mathrm{T}_{2}(\mathrm{FYM} 40 \%+$ NPK $(150: 120: 120)$ i.e. (32.73). Similar findings were reported by Bindiya et al., (2006) in cucumber.

The maximum number of fruit per plants (15.19) was recorded with $\mathrm{T}_{5}$ (FYM $100 \%+$ NPK (150:120:120) followed by $\mathrm{T}_{4}$ (FYM $80 \%+$ NPK (150:120:120) i.e.(114.34), $\mathrm{T}_{3}$ (FYM 60\% + NPK (150:120:120:) i.e. (13.53) and $\mathrm{T}_{2}$ (FYM40\% + NPK (150:120:120) i.e.(12.12). The maximum number of fruit per plot (121.49) was recorded with $\mathrm{T}_{5}(\mathrm{FYM}$ $100 \%$ + NPK (150:120:120) followed by $\mathrm{T}_{4}$ $($ FYM $80 \%+\operatorname{NPK}(150: 120: 120)$ i.e. (114.75), T 3 (FYM60\% + NPK(150:120:120) i.e. (108.24) and $\mathrm{T}_{2} \quad(\mathrm{FYM} 40 \%+$ NPK(150:120:120) i.e. (96.96). The highest fruit length $(\mathrm{cm})(16.33)$ was recorded with $\mathrm{T}_{5}$ (FYM 100\% + NPK (150:120:120) followed by $\mathrm{T}_{4}(\mathrm{FYM} 80 \%+$ NPK (150:120:120) i.e. (15.49), T 3 (FYM60\% + NPK (150:120:120:) i.e. (15.48) and $\mathrm{T}_{2} \quad(\mathrm{FYM} 40 \%+$ NPK(150:120:120:) i.e. (14.83).The highest fruit diameter $(\mathrm{cm})(15.69)$ was recorded with $\mathrm{T}_{5}$ (FYM $100 \%+$ NPK $(150: 120: 120)$ followed by $\mathrm{T}_{4} \quad(\mathrm{FYM} 80 \%+\mathrm{NPK}$ (150:120:120) i.e. (14.24), $\mathrm{T}_{3}$ (FYM60\%+ NPK (150:120:120)i.e. (13.59) and $\mathrm{T}_{2}$ (FYM40\% + NPK(150:120:120) i.e. (13.53) However the lowest fruit diameter $(\mathrm{cm})$ was observed in $\mathrm{T}_{0}$ (control) (11.37). The minimum days to first harvest of fruit (55.48) was recorded with $\mathrm{T}_{5}$ (FYM 100\% + NPK (150:120:120) followed by $\mathrm{T}_{4}$ (FYM $80 \%+$ NPK (150:120:120) i.e. (56.73), $\mathrm{T}_{3}$ (FYM $60 \%+$ NPK (150:120:120) i.e. (59.15) and $\mathrm{T}_{2}$ (FYM40\% + NPK (150:120:120) i.e.(60.55). These results have been reported by Bindiya et al., (2006) and Ghasem et al., (2014) in cucumber and Singh et al., (2017).
The highest fruit weight (145.61) was recorded with $\mathrm{T}_{5}$ (FYM 100\%+NPK (150:120:120) followed by $\mathrm{T}_{4}(\mathrm{FYM} 80 \%+$ NPK (150:120:120) i.e. (138.62), $\mathrm{T}_{3}$ (FYM $60 \%+$ NPK (150:120:120) i.e. (136.69) and $\mathrm{T}_{2}$ (FYM40\% + NPK (150:120:120) i.e. (130.47). Similar results have also been reported by Choudhari and More (2002) and Khan et al., (2005) and Niu et al., (2008).

The maximum fruit yield per plant $(\mathrm{kg})(2.21)$ was recorded with $\mathrm{T}_{5}$ (FYM 100\% + NPK (150:120:120:) followed by $\mathrm{T}_{4}$ (FYM80\% + NPK (150:120:120:) i.e. (1.99), T 3 (FYM60\% + NPK (150:120:120:) i.e. (1.85) and $\mathrm{T}_{2}$ (FYM40\% + NPK (150:120:120:) i.e. (1.58). The maximum fruit yield per plot $(\mathrm{kg})(\mathrm{kg})$ (17.69) was recorded with $\mathrm{T}_{5}$ (FYM 100\% + NPK (NPK (150:120:120:) followed by $\mathrm{T}_{4}$ (FYM $80 \%+$ NPK (150:120:120:) i.e. (15.91), T 3 (FYM 60\% + NPK (150:120:120:) i.e. (14.80) and $\mathrm{T}_{2}$ (FYM40\% + NPK (150:120:120:) i.e. (12.65). Similar results have been reported by Sinikov et al., (1992), Khristov and Rankov (1992) and Choudhari and more (2002) and Bindiya et al., (2006).

The maximum fruit yield $\left(\mathrm{t} \mathrm{ha}^{-1}\right)$ (81.90) was recorded with $\mathrm{T}_{5}$ (FYM $100 \%+\mathrm{NPK}$ (150:120:120:) followed by $\mathrm{T}_{4}$ (FYM 80\%+ NPK(150:120:120:) i.e. (73.64), $\mathrm{T}_{3}$ (FYM $60 \%+$ NPK (150:120:120:) i.e. (68.50) and $\mathrm{T}_{2} \quad$ (FYM40\% + NPK (150:120:120:) i.e.(58.56). Increase in the yield due to higher levels of nitrogen application has been reported by Jassal et al., (1970), Randhawa et al., (1981), Deswal and Patil (1994), and Singh and Chhonker (1986).

The maximum TSS (Brix) (4.90) was recorded with $\mathrm{T}_{5}$ (FYM $100 \%+\mathrm{NPK}$ (150:120:120) followed by $\mathrm{T}_{4}$ (FYM $80 \%+$ NPK 150:120:120) i.e. (4.41), $\mathrm{T}_{3}$ (FYM 60\% + NPK 150:120:120) i.e. (4.25) and $T_{2}$ (FYM40\% + NPK (150:120:120) i.e. (3.79). The maximum Vitamin $\mathrm{C}(8.54)$ was recorded 
with $\mathrm{T}_{5}$ (FYM 100\% + NPK (150:120:120) followed by $\mathrm{T}_{4}$ (FYM $80 \%+\mathrm{NPK}$ (150:120:120) i.e. (7.91), $\mathrm{T}_{3}$ (FYM60\% + NPK (150:120:120) i.e. (7.53) and $\mathrm{T}_{2}$ (FYM40\% + NPK (150:120:120) i.e. (7.31). Similar findings were reported by Eifediyi and Remison (2010) in cucumber and Okoli and Nweke (2015) and Singh et al., (2017).

\section{References}

Bindiya, Y, Reddy, I. P; Srihari D; Narayanamma, M. and Reddy, R. S (2006) Effect of integrated nutrient management on growth and yield of cucumber (Cucumis sativus L.). J. Res. ANGRAU. 34: 4,8-1

Choudhari, S. M. and More and T. A. (2002). Fertigation, fertilizer and spacing requirement of tropical gynoecious cucumber hybrids. Acta Horticulturae. 588, 233-240.

Costa, E. Leal, P. A. M. Gomes, V. do A. Machado, D. Jara and M. C. de S. (2010). Biomass of hybrid cucumber seedlings in protected environments. [Portuguese Bragantia. 69: 2,381-386.

Deswal, I.S. and Patil, V.K. (1984). Effect of $\mathrm{N}, \mathrm{P}$ and $\mathrm{K}$ on the fruit of watermelon. J. Maharashtra Agric. Unvi., 9(3): 308309.

Eifediyi EK, Remison SU. (2010). Growth and yield of cucumber (Cucumis sativus L.) as influenced by farmyard manure and inorganic fertilizer. J. of Plant Breeding and Crop Science. 2010; 2(7): 216-220.

El-Shewy, A. A. (1999). Physiological studies on sweet melon nutrition under sandy soil condition. Annals of Agri. Sci., Moshtohor.37:2, 1201-1220.

Ghasem S, Morteza AS, Maryam T. (2014). Effect of organic fertilizers on cucumber (Cucumis sativus) yield. I.J.A.C.S. 2014; 7(11):808-814.

Gopalan, C., Rama Satri, B.V and
Balasubramanian, S.C. (1982).Nutritive value of Indian Food. Indian Council of Medical Res. National Institute of Nutritive, Hyderabad.

Jackson, M.L. (1973). Soil Chemical Analysis. Prentice Hall of India Pvt. Ltd., New Delhi. Pp 370-87.

Jassal, N.S. Randawa, K.S. and Nandpuri (1970). A study on the effect of irrigation and certain does of $\mathrm{N}, \mathrm{P}$ and $\mathrm{K}$ on the weight of fruit and yield of muskmelon. Punjab Hort. J., 10 : 143149.

Khan, A. U. Muhammad Subhan Khan, A. U. and Khan Bahader (2005). Effect of NPK alone and in combination on the growth and yield of cucumber. Indus $J$. plant Sci., 4:4, 428-431.

Khristov, B. and Rankov, V. (1992). Effect of the date mineral fertilizer application on the productivity and of biological removal of nutrient by melons. [Bulgarian] Pochvoznanie, Agrokhimiyay Ekologiya. 27: 3-4, 41-45.

Li ZhenZhen, Wu Jue, Yang YinJuan, Cao HuanHuan, Niu QingLiang and Huang DanFeng (2011). Effect of soil conditioners on cucumber growth and soil conditions under protected culture .Acta Agri. Shangai. 27: 2, 87-91

Okoli PSO, Nweke IA. (2015). Effect of poultry manure and mineral fertilizer on the growth performance and quality of cucumber fruits. J. of Experimental Biology and Ag. Sc. 2015; 3(4):362367.

Randhawa, K.S., Cheema, D.S. and D.S. Sandhu (1981). The effect of nitrogen, phosphorous and potassium on the growth, yield and quality of new muskmelon varieties. Haryana J. Hort. Sci. 10(1/2): 88-94.

Robinson, R. W. and Whitaker, T. W. (1974). Cucumis. In R. C. King (ed.)., Hand Book of Genetics Vol. 2, p 145-150

Singh Vishal, VM Prasad, Saurabh Kasera, 
Bhanu Prakash Singh and Sudhir Mishra (2017). Influence of different organic and inorganic fertilizer combinations on growth, yield and quality of cucumber (Cucumis sativus L.) under protected cultivation. Journal of Pharmacognosy and Phytochemistry 2017; 6(4):10791082

Sinikov, D. Mukhammedov, A. and Baisakhatov, R. (1992). Effect of fertilization on the productivity of the melon cultivar Vakharman-499 in Tedzhensk region. [Russian] Izvestiya Akademii Nauk Turkmenistana. Seriya Bioloogicheskih Nauk. 3, 17-22.
Umamaheswarappa, P. Gowda, V. N. and Murthy P. V. (2005). Nitrogen, phosphorus and potassium content in vine, leaf, fruit and root of cucumber cv. Poinsette as affected by varying levels of NPK. Mysore J. Agri. Sci. 39: 2, 275 280.

Umamaheswarappa, P. Gowda, V. N. and Murthy P. V. (2005). Nitrogen, phosphorus and potassium uptake and fruit-size of cucumber (Cucumis sativus L.) cv. Poinsette as influenced by different levels of $\mathrm{N}, \mathrm{P}$ and $\mathrm{K}$. Karnataka J. Hort., 1: 3, 76-80.

\section{How to cite this article:}

Patil Sruthi and Prasad, V. M. 2020. Study on Influence of FYM Doses and NPK on Growth Yield and Quality of Hybrid Cucumber (Cucumis sativus L.) under Shade Net. Int.J.Curr.Microbiol.App.Sci. 9(10): 3548-3555. doi: https://doi.org/10.20546/ijcmas.2020.910.409 